Discussion Paper No. 15-009

Minimum Participation Rules in International Environmental Agreements:

Empirical Evidence from a

Survey among Delegates in International Climate Negotiations

Martin Kesternich

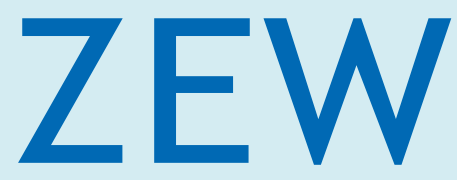

Zentrum für Europäische Wirtschaftsforschung $\mathrm{GmbH}$

Centre for European

Economic Research 
Discussion Paper No. 15-009

\title{
Minimum Participation Rules in International Environmental Agreements: Empirical Evidence from a Survey among Delegates in International Climate Negotiations
}

\author{
Martin Kesternich
}

Download this ZEW Discussion Paper from our ftp server:

http://ftp.zew.de/pub/zew-docs/dp/dp15009.pdf

Die Discussion Papers dienen einer möglichst schnellen Verbreitung von neueren Forschungsarbeiten des ZEW. Die Beiträge liegen in alleiniger Verantwortung der Autoren und stellen nicht notwendigerweise die Meinung des ZEW dar. 


\title{
Minimum Participation Rules in International Environmental Agreements: Empirical Evidence from a Survey among Delegates in International Climate Negotiations
}

\author{
Martin Kesternich
}

Version: February 5, 2015

\begin{abstract}
:
Recent contributions to the theoretical and experimental literature suggest that minimum participation rules (MPRs) are able to reduce free-riding incentives and may facilitate cooperation (or at least coordination) at the extensive margin of international environmental agreements. Based on a dataset from a world-wide survey among delegates in international climate negotiations, this paper assesses preferences for different MPRs for a future climate treaty among key players. The empirical findings provide evidence that small countries with low bargaining power rather opt for large minimum membership requirements while industrialized countries push forward the idea of a small carbon club of the largest emitters only. In contrast, delegates from countries in transition try to keep emission thresholds rather low which would allow a future agreement to come into force without their signature.
\end{abstract}

Keywords: international climate negotiations, minimum participation rules

JEL: C72, C92, H41

\section{Acknowledgement:}

I thank Martin Achtnicht, Astrid Dannenberg, Anke Gerber, Andreas Lange, Andreas Löschel, Sascha Rexhäuser, and Bodo Sturm for very valuable comments and suggestions on the paper. Moreover, the paper has benefited from discussions with participants of the econometrics seminar at ZEW

Financial support by the German Federal Ministry of Education and Research (FKZ 01UN1016A) and the German Academic Exchange Service (DAAD) is gratefully acknowledged. Further details can be obtained from http://www.zew.de/staff_mkn and the ZEW Annual Report (http://www.zew.de/en/publikationen/jahresbericht.php3).

Correspondence: Martin Kesternich, Centre for European Economic Research (ZEW), L 7,1, 68161 Mannheim, Germany, kesternich@zew.de 


\section{Introduction}

Collective action problems like global climate change create strong free-riding incentives among negotiating parties. To overcome the social dilemma situation, any adequate institutional design relying on voluntary contributions has to cope with two major challenges: First, at the extensive margin, any agreement has to ensure the participation of sufficient (key) players. Second, at the intensive margin, participants have to agree upon a joint provision level of the public good and allocate the burden among the different parties. Theoretical predictions from the coalition formation literature on international environmental agreements (IEA) are rather pessimistic especially when the difference in net benefits between the noncooperative and the cooperative outcome is large: any self-enforcing IEA will be signed only by a few number of countries and efficiency gains remain modest (e.g., Hoel 1992, Carraro and Siniscalco 1993, Barrett 1994).

Recent theroretical contributions to this literature (Black et al. 1993, Rutz 2001, Harstad 2006, Carraro et al. 2009, Weikard et al. 2012) and experimental investigations (e.g., Kosfeld et al. 2009, Gerber et al. 2013, McEvoy et al. 2014) suggest minimum participation rules (MPRs) to hamper free-riding incentives and to facilitate cooperation at the extensive margin. A corresponding minimum participation clause ensures that a treaty only enters into force if a certain threshold such as a minimum number of ratifying countries is met. Signatories are therefore not obliged to commit to any obligation of an agreement until enough other agents agree to join the treaty. Barrett (1998a) argues that exougenously determined minimum participation rules ususally fail to meet the self-enforcement criterion but may serve as a coordinating advice to overcome a tipping point to the mutually preferred equilibrium.

Rutz (2001) studied 122 IEA treaty texts and only identifies two agreements without any minimum participation rule. The Kyoto Protocol, negotiated in 1997, established a "double trigger” which required (i) at least 55 parties of the United Nations Framework Convention (UNFCCC) that (ii) account for at least 55\% of total Annex I carbon emissions in 1990 to ratify the agreement before it entered into force. While the first condition of this double trigger was rapidly met (100 parties in 2003 and currently 192 signatories), the second part remained challenging for several years until the protocol finally entered into force in 2005. By the end of 2002, ratifying countries accounted for about 44\% of 1990 carbon emissions (UNFCCC 2002). After Australia and the USA stated that they will not join the treaty, Russia (17.4\% of 1990 emissions) became the pivotal player in the negotiation process which finally 
led to the well-known "hot-air" or "carbon-bubble" phenomenon of the Kyoto Protocol (e.g., Paltsev 2000, Bernard et al. 2003, Böhringer and Vogt 2003, 2004). In many treaties, the actual number of parties exceeds the minimum participation threshold. This observation may provide evidence for the coordination device to be the predominant effect of this mechanism rather than being able to deter free-riding (Barrett 1999). Following this argument, Rutz (2001) concludes that MPRs may not result in substantial improvements of the environmental quality since requirements of the treaty do not go far beyond what a country would have done in absence of an agreement.

While several studies empirically assess preferences for different burden sharing rules among participants in international climate negotiations (Lange et al. 2007, Lange et al. 2010, Hjerpe et al. 2011, Kesternich et al. 2014 ${ }^{1}$ ) there is considerable less empirical evidence with respect to the institutional design at the extensive margin. Since negotiating parties have to agree upon specific minimum requirements, studying preferences for different MPRs empirically is an important step to identify possible pathways and obstacles for these instruments in a future climate deal. Black et al. (1993) predict that countries expecting high benefits from an agreement will opt for lower minimum participation rule in order to ensure that the agreement will enter into force. Harstad (2006) reveals that the threshold should be smaller if the heterogeneity of agents is large but increase if the externality is high.

The Lima call for climate action, adopted by the UNFCCC during its recent COP-20 meeting in Peru, aims at laying out the policy basis for a new bottom-up global climate regime and highlights the importance of entry into force conditions (UNFCCC 2014). In its elements for a draft negotiation text, Article 95.2 includes five different options for entry into force conditions that contain minimum participation rules with respect to a minimum number of ratifying countries and/or a minimum share of global greenhouse gas (GHG) emissions. So far, the exact values of these different shares remain unspecified in the draft negotiation text.

Based on a dataset from a world-wide survey among delegates in UNFCCC climate negotiations (COP-16 in Cancún in 2010 and COP-17 in Durban in 2011) the aim of this paper is to investigate the perception of different MPRs for a future climate treaty among key players. In particular, I study individual preferences with respect to the stringency for (i) a minimum number of UNFCC member states (minimum membership threshold) and (ii) a minimum percentage rate of global GHG emissions (minimum emission threshold). While

\footnotetext{
1 The paper by Kesternich et al. (2014) is based on data from the same underlying questionnaire that consisted of different parts. Further analyses based on this data are conducted by Meulemann and Ziegler (2013) and Meulemann (2014).
} 
stricter requirements may broaden participation and therefore lead to more cost-effective agreements, they may increase veto power for non-signatories and they are also more susceptible to coordination failures. This paper may therefore add to the debate whether to allow for sub-agreements among a small number of key players (“carbon clubs”) instead of a comprehensive and rigid large-scale agreement (Victor 2011).

In line with the discussions during the Kyoto process, the econometric analysis provides evidence that in particular preferences for minimum emission thresholds substantially differ among negotiating parties. While industrialized countries push forward the idea of small carbon clubs, small countries with low bargaining power rather opt for large membership requirements. In contrast, delegates from countries in transition with high current GHG emissions try to keep emissions thresholds rather low which might allow them to stay away from a forming coalition.

The remainder of the paper is structured as follows: Section 2 summarizes the existing theoretical literature and some related experimental evidence. Section 3 contains the empirical analysis and a discussion of the econometric results. The last section concludes.

\section{Minimum Participation Rules in International Environmental Agreements}

The theoretical literature on coalition formation (e.g., Hoel 1992, Carraro and Siniscalco 1993, Barrett 1994) usually involves a $N$-player two-stage cartel formation game: In the first stage, agents non-cooperatively decide whether to join or not to join a coalition. In the second stage, both the coalition (with $k$ signatory countries) and the non-signatories $(N-k)$ decide upon their contribution to the public good. The predictions of these models are rather pessimistic: Because of strong free-riding incentives, any self-enforcing IEA will be signed only by a small number of countries. Theoretical extensions to the coalition formation literature to address the free-riding problem include among others preferences for equity (e.g., Lange and Vogt 2003), a partial or modest internalization of joint benefits of the coalition members (Finus and Maus 2008) or a minimum participation threshold that has to be met until an agreement enters into force (Rutz 2001, Carraro et al. 2009, Weikard et al. 2012).

Black et al. (1993) are among the first who analyze the effect of an exogenously determined MPRs on cooperation. In their model, countries are identical with respects to abatement costs but there is ex-ante uncertainty about individual benefits. Depending on the parameter values, their results suggest that a minimum membership threshold may enlarge the coalition and 
increase efficiency in contrast to the non-cooperative outcome. They further report that under certain conditions countries expecting high benefits from an agreement will favor a lower minimum participation rules in order to ensure that the agreement will enter into force.

Rutz (2001) considers an exogenously determined MPR in a two-stage coalition formation model. With identical countries, efficiency gains are feasible if the required minimum threshold $(\bar{k})$ is set higher than $k$ in the non-cooperative solution. Harstad (2006) describes minimum thresholds as an intermediary solution between voluntary or flexible cooperation (that causes strong free-riding incentives) and a rigid approach (that treats all heterogeneous agents equally). In his model, the contribution to the public good is a binary decision among agents differing in their net benefits from the joint project. The analysis shows that the minimum participation threshold should be smaller if the heterogeneity of the agents is large but larger if the externality is high. Reasonable concerns however remain that a specific MPR exists that beats every other alternative in a pairwise vote after the heterogeneity among negotiating agents has been realized and thus prevents the political equilibrium.

Carraro et al. (2009) extend the standard two-stage coalition game by introducing an additional pre-stage (the minimum participation stage) where identical agents agree upon the minimum share of ratifying countries by unanimity voting. This theoretical framework predicts an endogenous MPR to facilitate coalition formation and to strengthen cooperation. If the net benefits from coalition formation are increasing rapidly with the number of signatories even full cooperation is possible. Agents prefer to "tie their hands" in the minimum participation stage and give up the possibility to free-ride in the following stages to ensure cooperation gains from the grand coalition (Carraro et al. 2009: p. 422).

In a related study, Weikard et al. (2012) consider a minimum participation stage with simultaneous ratification in a setting where players differ with respect to their costs and benefits. In a first stage, a randomly chosen country proposes a minimum abatement threshold that has to be accepted by unanimity voting. The grand coalition is an equilibrium outcome if the bargaining power of the proposing agent is small or the free-rider proposal of the powerful player is unacceptable to at least one other agent. Comparing payoffs of pivotal countries under participation and non-participation, the model further predicts that players prefer to be non-pivotal instead of being pivotal for an agreement in a simultaneous game since pivotal players lack any credible threats to not join the coalition. Under certain assumptions, the proposing country can exploit a first-mover advantage by reducing the minimum participation level such that it can exploit a non-pivotal position. Therefore, equilibria may exist where at 
least one country is able to free-ride on the coalition's gains. It remains an open question whether sequential accession, a probably more realistic assumption, alters these predictions. Empirical evidence from Russia's role in the Kyoto process however suggests that sequential accession to a treaty may imply that (some) players become pivotal at a certain stage and can bargain with the signatories (Weikard et al. 2012: p. 17).

Recent theoretical work on minimum participation clauses consider second-best agreements which do not require to fully internalize the welfare gains of the cooperative coalition (Courtois and Haeringer 2012). Other related papers relax the frequent assumption of considering players as unitary actors to allow for an interaction between negotiators and voters (Köke and Lange 2013).

Barrett (2003) summarizes some of this literature and argues that an arbitrary chosen minimum participation level usually lacks the self-enforcement criteria and is vulnerable to renegotiations. MPRs may therefore rather serve as a coordination device. Analyzing the Kyoto process, Barrett (1998) concludes that although MPRs in the protocol may have helped to reduce free-riding at least to some extent they did not provide adequate incentives to increase participation beyond the minimum threshold. Barrett and Stavins (2003) even draw are more pessimistic conclusion concerning the effectiveness of minimum participation clauses based on the fact that the Kyoto Protocol finally could enter into force with emissions reduction targets for countries that accounted for less than 20 percent of global emissions.

The experimental literature has recently begun to explicitly investigate the membership decision in the coalition formation framework. In Kosfeld et al. (2009), subjects in a first stage decide whether to join a coaliton. The (potential) coalition members then decide whether to implement the institution and to contribute their full endomwent by unanimity voting. The results suggest that the majority of all groups of four homogenous players establishs the grand coalition. Smaller coalitons, although being profitable from a theoretic point of view, are rejected in most cases. If an institution is formed, contributions to the public good are higher and more stable in contrast to an uncoordinated action. Gerber et al. (2013) investigate the impact of different exogenously determined minimum participation thresholds in a 4-players public goods experiment with homogeneous agents. They report that weaker institutions do not facilitate coalition formation and thus do not lead to efficiency gains in contrast to a full participation rule. Under weaker institutions, many groups accept one player to free-ride on the coalition gains which suggests inequality aversion to be rather moderate among agents. McEvoy et al. (2014) evaluates the performance of an endogenously 
determined minimum participation threshold both in setting when efficiency results in the grand coalition and when it only requires a 50\% membership. In the first stage, participants in groups of six homogenous players agree upon a minimum membership requirement by majority voting. In the second stage, each player decides whether to join or not to join the coalition. If the coalition is formed, signatories contribute to the public good while nonsignatories do not contribute. If coalition formation fails, no one contributes to the joint project. The authors report high efficiency gains, especially when efficiency requires full participation. When efficiency requires only a subset of players and therefore permits freeriding on the coalition gains, the coalition is blocked in about one third of the cases which is, in contrast to the findings by Gerber et al. (2013), consistent with inequality aversion in social preferences models.

Both the theoretical and the experimental literature provide evidence that MPRs may broaden participation and foster cooperation (or at least coordination) in the provision of international public goods. MPRs are a common feature of many international environmental agreements and an established component both of the UNFCCC and the Kyoto Protocol. Taking a closer look into the development of the double trigger in the Kyoto process however reveals some interesting insights on potentially different positions among key players. While AOSIS (Alliance of Small Island States), Japan, Switzerland and Russia put forward the idea of including a certain number of UNFCCC member states, the US delegation called for a certain minimum threshold of carbon emissions (UNFCCC 2000). A proposal made by the Norwegian delegation addressed the different positions by proposing a first version of the double trigger approach of both MPRs requiring the ratification of 50 UNFCCC member states and $75 \%$ of Annex I emissions. During the negotiation process, parties rapidly agreed upon 50 member states but differ with respect to the share of emissions that should be accounted. Japan and Canada voted for a 75\% threshold level and the Chinese/G-77 position called for a figure not higher than 50\%. In the final plenary the (almost) mid-way position of $60 \%$ was again lowered to $55 \%$ by the Chairman in order to reduce veto power of any one or two countries "[a]lthough non-ratification by any two of the three highest Annex I emitters, the US, the EU and the Russian Federation, could still, together, prevent entry into force" (UNFCCC 2000, footnote 68).

Closest to the empirical strategy presented in this paper is a study by Beron et al. (2003) who assess ratification decisions of countries with respect to the Montreal Protocol on Substances that deplete the Ozone Layer. In particular, they focus on the impact of interdependences between countries on cooperation which may exist at least to two reasons. First, the protection 
of the ozone layer is an international public good which creates strong free-riding incentives such that ratification decisions are not independent. Second, international trade flows may create bargaining power for some (importing) countries over other (exporting) countries. Their data suggest that neither free-riding incentives nor decisions of the largest trading partners significantly influenced countries’ decisions.

\section{Empirical Analysis}

\subsection{Data Description}

The data for the empirical analysis is obtained from a world-wide survey among delegates in international climate negotiations. A standardized web-based questionnaire was sent via email to 5,767 experts in climate policy in April 2012. The contact details were derived from official UNFCCC lists of participants from the COP-16 in Cancún in 2010 and from COP-17 in Durban in 2011. In addition, national focal points were contacted. ${ }^{2}$ There was an individual login available for each participant to ensure that the questionnaire was only filled out once by each individual. In order to prevent possible shortcomings because of limited internet access in certain regions, participants additionally had the possibility to send back fillable PDF forms via email, postal mail, or fax. In May and June 2012, two reminders were sent out including some additional contact information that was obtained from first-round participants. In total, 5,840 individuals were contacted. 498 participants sent back their answers (response rate: 8.5\%). About $72 \%$ of the participants stated information of their personal backgrounds. Since not all participants shared their attitudes towards all parts of the survey or break-off the questionnaire, the analyses in this paper are based on up to 247 observations from 96 countries.

\subsection{Econometric Models and Variables}

For the econometric analysis, I consider two different dependent variables: (i) the stated minimum number of UNFCCC member states and (ii) the stated minimum percentage share of global GHG emissions needed for a future climate agreement entering into force. Both variables are limited rather than continuous with lower and upper tail limits of 0 and $z$ with (i) $z=195$ or (ii) $z=100$. True values might be just equal to the threshold, but they might also be lower or higher. The perceived difference, for instance, between indicating a “0” or a

\footnotetext{
2

2 The list of participants for the COPs remain in many cases preliminary due to many ad-hoc changes in attendances. Therefore, not all members of the list of participants have been actually participated in the COP. I control for this issue in the empirical analysis.
} 
positive value might be larger than just the simple absolute value. Similar considerations hold for observations at $z=195$ or (ii) $z=100$ in contrast to lower values. OLS regression does not account for the censoring and may therefore lead to inconsistent results. A Tobit model therefore provides an appropriate estimation technique to account for tail limits. The underlying latent variable framework for each individual $i=1, \ldots, N$ is given by

$$
y_{i}^{*}=\boldsymbol{x}_{i}^{\prime} \boldsymbol{\beta}+\varepsilon_{i}
$$

where $\boldsymbol{x}_{i}$ is the vector of explanatory variables, $\boldsymbol{\beta}$ is the related vector of coefficients and $\varepsilon_{i} \sim N\left(0, \sigma^{2}\right)$ is the corresponding error term. The observed variable $y_{i}$ relates to the unobserved latent variable $y_{i}^{*}$ as follows:

$$
y_{i}=\left\{\begin{array}{r}
0 \text { if } y_{i}^{*} \leq 0 \\
y_{i}^{*} \text { if } y_{i}^{*}>0 \\
z \text { if } y_{i}^{*}>z
\end{array}\right.
$$

Since the distributions of the dependent variables indicate that responses may be categorized into different classes along certain focal points rather than being continuous (between the two tail limits), as an additional robustness check, I transform the dependent variable into a categorical variable with known cell limits based on four categories (see Table A2). The first category contains observations that indicated no requirements $(=0)$ with respect to the different minimum thresholds. The second category includes observations in the range from larger than zero up to a threshold of (i) 55 countries or (ii) 55\% of global GHG emissions which corresponds to the numbers in the Kyoto Protocol. ${ }^{3}$ The third category covers all observations that require larger minimum thresholds. The fourth category captures all observations at the upper boundary. With the assumption $\boldsymbol{x}_{i} \sim N\left(\boldsymbol{x}_{i}^{\prime} \boldsymbol{\beta}, \sigma^{2}\right)$ where $\sigma^{2}=$ $\operatorname{var}\left(y_{i}^{*} \mid \boldsymbol{x}_{i}\right)$ such interval-coded data can be used for interval regression with maximum likelihood (Wooldridge 2002). Cell limits are defined as $a_{1}<a_{2}<a_{3}<a_{4}$ and the error term is assumed to be normally distributed. This approach differs from the standard ordered probit model where (unknown) cell limits have to be estimated and where, in many cases, stricter distributional assumptions have to be fulfilled. In the following, I examine several determinants that may influence the assessment of the minimum emissions thresholds $\left(\mathrm{MPR}_{\mathrm{EM}}\right)$ and the minimum participation thresholds $\left(\mathrm{MPR}_{\mathrm{UN}}\right)$.

Country groupings: The Durban Platform for Enhanced Action, adopted by the international community at COP-17 in 2011, serves as a mandate within the UNFCC to develop an agreed

\footnotetext{
3 Note that the Kyoto Protocol required 55\% of total Annex I carbon emissions while the number in this survey, as in the Lima call for climate action, refers to global GHG emissions.
} 
outcome with legal force to all Parties no later than 2015. An important notion of this framework is the call for the "widest possible cooperation by all countries and their participation in an effective and appropriate international response” (UNFCCC 2012: p.2). This elimination of the traditional binary Annex I/non Annex I distinction of the Kyoto process is perceived as a crucial step to get countries on track for a comprehensive agreement that includes all major emitters (e.g., Aldy and Stavins 2012, Edenhofer et al. 2013).

An obvious starting point for the analysis on country group effects is to distinguish between member states with binding emission targets in the Kyoto Protocol, the 39 so called Annex B countries (UNFCCC 1998, Article 3), and those without any binding obligations, captured by the binary variable ANNEX B. This group includes all major industrialized countries but no large emerging countries like China, Brazil or India. I suspect delegates from Annex B countries to opt for high emissions thresholds such that the accession of large countries in transition with high GHG emissions becomes essential for a treaty to enter into force. At the same time, Annex B countries may rather vote for smaller minimum participation thresholds. Such small "carbon clubs” may provide an opportunity to reduce complexity and facilitate negotiations on GHG emission reduction targets (Victor 2011).

In a second step, I follow the UNFCCC party groupings (UNFCCC 2013) and I distinguish between five different regional country groups to address potential changes in constellations of countries since the Kyoto process: AOSIS, BASIC, EU27, UMBRELLA/EIG and G77 (without its AOSIS and BASIC members). ${ }^{4}$ The AOSIS coalition covers a group of 43 small island countries that face high levels of vulnerability with respect to changes in the climate system (i.e., sea-level-rise). The BASIC group (Brazil, South Africa, India and China), initiated and led by China, unifies four large emerging countries out of the G77 group that was initially formed during the negotiations on the Copenhagen Accord in November 2009 (Olsson et al. 2010). ${ }^{5}$ EU27 covers the European Union and its member states and is itself a Party of the UNFCCC (Economic integration organization) but without any additional voting rights apart from those of its member states. The UMBRELLA/EIG (former JUSSCANNZ) group represents the position of non-EU industrialized countries. It is a non-formal list including Australia, Canada, Japan, New Zealand, Norway, Russia, the Ukraine and the US

\footnotetext{
${ }^{4}$ In some cases delegation members worked for different parties in COP-16 and COP-17. I chose the stated home country as the appropriate variable for assigning the participants to the different country groups. Taking into account all survey participants, in most of the cases (95.4\%) delegation members represented their home country in COP-16 and/or COP-17. Only in 15 cases, respondents in both COPs were delegation members of a party which was not his or her stated home country or region. As an additional robustness check, I excluded these observations from the analysis. This did, however, not affect the main results. Throughout the paper the discussion is based on the full sample.

${ }^{5}$ It should be noted that we did not get any responses from India in our survey. When I refer to BASIC throughout the paper, the results do not necessarily reflect the Indian position within the group.
} 
and the members of the Environmental Integrity Group (EIG) (formed in 2000) consisting of Mexico, Liechtenstein, Monaco, the Republic of Korea and Switzerland. Table A1 provides an overview of the respective country groups. Table A3 summarizes country-level data on GDP and current carbon emissions levels for different countries and regions. When the different UNFCCC party groupings enter the econometric analysis, G77 countries serve as the base category.

Share of global GHG emissions: An important measure that may influence the assessment of MPRs in a future climate agreement is the share of current global GHG emissions of the respective country. As discussed in the previous section, the second part of the double trigger in the Kyoto Protocol required ratifying countries to cover at least $55 \%$ of total Annex I carbon emissions. I therefore expect that 2011 emissions levels $\left(\mathrm{CO}_{2}\right)$ will affect decision behavior, mainly in terms of MPR $\mathrm{EM}_{\mathrm{EM}}$. In line with the estimation strategy proposed by Beron et al. (2003), I jointly consider variables on country groupings together with emission levels in order to separate the developmental effect from the level-of-emissions effect (columns 1 and 4 in Table 2 and 4, columns 1 and 3 in Table 3 and 5). As an alternative approach to disentangle this effect, I control for the ratio of greenhouse gas emissions produced relative to gross domestic product in 2011 ( $\mathrm{CO}_{2}$ perGDP) (columns 2 and 5 in Table 2 and 4, columns 2 and 4 in Table 3 and 5 ). This variable is calculated based on GDP data from the World Bank (2014). Due to the relationship between ANNEX B and GDP (at least at per capita levels) ( $\rho$ $=0.77$ ), in a further robustness check, I focus on per capita GDP (GDPpc) and an interaction term of GDPpc and $\mathrm{CO}_{2}\left(\mathrm{CO}_{2} \mathrm{XGDPpc}\right)$ without controlling for any party groupings (columns 3 and 6, Table 2 and 4).

Although recent trends in global GHG emissions may provoke a future shift concerning the importance of different key players, highly developed countries will probably not be accepted to stay away from any future commitments due to their historical responsibility and their economic capacity. If that was possible, this might provide incentives to suggest a lower emission threshold. However, in order to ensure mitigation commitments from all major emitters and to foster participation from economies in transition, developed countries are expected to vote for more ambitious minimum emission thresholds. In contrast, emerging countries may insist that developed countries should take the lead and may claim their right for development. These countries may therefore call for lower minimum emission requirements allowing them to free-ride on gains of a coalition formed by other countries. In line with this argument, emerging countries may also indicate lower minimum emission 
thresholds in order to reduce the likelihood of being pivotal for an agreement which, according to the predictions by Weikard et al. (2012), may reduce their bargaining power.

Vulnerability to climate change: Expected impacts and risks of climate change are unevenly distributed and are generally more severe for indivdiuals in developing countries (IPCC 2013). They include climate-related wheather extremes such as heat waves, droughts, floods, cyclones or wildfires. Since comparable global data on national vulnerability levels is limited, I use coastline data from the CIA World Factbook (2014) to control for a potential relationship between the vulnerability to climate change and the assessement of MPRs. According to the IPCC, global mean sea levels will continue to rise in the future due to an increase in the ocean temperature and an increased loss of mass from glaciers and ice sheets. Expected impacts for coastal systems and low-lying areas such as the AOSIS states include submergence, coastal floodings and coastal erosion. In line with the predicitons derived by Black et al. (1993), countries with long coastlines and therefore higher benefits from the public good may favor less restrictive membership requirements to accelerate negotiations towards a successful outcome. In contrast, countries being particularly vulnerable to climate change usually possess little bargaining power in international climate negotiations and may instead rather opt for broad participation levels to strengthen their role in future negotiations

Form of Government: A number of studies examine the relationship between the form of government and pollution levels (e.g., Congleton 1992, Barrett and Graddy 2000, Neumayer 2002). They report more democratic societies to value environmental quality to a relatively larger degree. Barrett and Graddy (2000) find an increase in civil and political freedom to improve national environmental quality for different air pollution variables. Neumayer (2002) studies environmental commitment assessed through the ratification of different multilateral environmental agreements (Kyoto Protocol, Copenhagen Amendment to the Montreal Protocol, the Rotterdam Convention and the Cartagena Protocol on Biosafety). Except for the Rotterdam Convention, the results suggest civil and political freedom to exhibit stronger international environmental commitents than non-democracies. Beron et al. (2003) confirm this relationship for the Montreal Protocol agreement negotiated in 1987. These papers argue that authoritarian regimes are less likely to commit to long-term agreements since dictators usually prefer decisions over relatively short time horizons due to uncertainties about the future. Following these observations, I hypothize delegates from countries with more democratic forms of governments to call for broader participation rates in a future climate deal. As suggested in the previous studies, I include a binary variable FREE that equals to one 
for countries with the highest freedom status taking into account both political rights and civil liberty constructed by Freedom House (2014). ${ }^{6}$

Self-assessment of bargaining power: Sequential accession to a treaty with a minimum participation clause may imply that (some) players become pivotal at a certain stage and can bargain with the signatories. As discussed previously, Russia became decisive for the Kyoto Protocol to enter into force after Australia and the USA stated not to ratify the agreement. In line with the argument of the expected impact of vulnerability on response behavior, delegates perceiving their bargaining power to be rather low may vote for high participation thresholds. To test this relationship, I construct an indicator variable POWERFUL that equals to one if the delegates perceives the bargaining position of their country to be "very powerful" or "powerful”, and zero otherwise. ${ }^{7}$

Further sociodemographic information like the respondents' age, sex, educational background or working field serve as additional control variables. Moreover, I take into account whether respondents were delegation members of national parties in COP-16 or/and COP-17 (about $78 \%$ of all participants). These variables however do not alter the main effects and are therefore not explicitly shown in the regression tables. Table A4 provides an overview of all explanatory variables with a brief description and summary statistics.

\subsection{Empirical Results}

The descriptive results indicate average minimum membership thresholds for a future climate regime across all survey participants to amount to 60 countries (about 31\% of all UNFCCC member states) (Table 1). While 32.8\% of all respondents opt for a rule that does not exceed the Kyoto commitments (55 countries), 46.2\% call for broader minimum participation rates. Considering minimum emissions thresholds, the assessment of the delegates reflects a more ambitious position, covering $44.4 \%$ of all global carbon emissions. $40.1 \%$ of all participants even suggest that an agreement should not enter into force until ratifying countries account for more than 55\% of global emissions. These observations again stress the importance of large emitters like China (28.1\% of global $\mathrm{CO}_{2}$ emissions in 2011, see Table A3) and the USA (15.9\% of global $\mathrm{CO}_{2}$ emissions in 2011) in the negotiation process. Rejection rates (i.e., no requirements) are larger for $\mathrm{MPR}_{\mathrm{UN}}(21.0 \%)$ than for $\mathrm{MPR}_{\mathrm{EM}}(16.2 \%)$. Figure A1 illustrates substantial differences in positions for emission thresholds among country groups. As

\footnotetext{
${ }^{6}$ The variable is constructed based on a three point scale (not free, partly free, free).

${ }^{7}$ The variable is constructed based on a four point Likert scale (very powerful, powerful, moderately powerful, not powerful).
} 
expected, average indicated $\mathrm{MPR}_{\mathrm{EM}}$ are largest among UMBRELLA/EIG members (mean: 58.5\%, median: 66\%) and lowest among negotiators from BASIC countries (mean: 31.0\%, median: 20\%). The median threshold suggested by the UMBRELLA/EIG countries would hardly allow for an agreement to enter into force without the membership of the BASIC group who are responsible for 35.8\% of all GHG emissions in 2011. Analogously, only a small minority of UMBRELLA/EIG participants would accept an agreement without any MPR $\mathrm{EM}_{\mathrm{E}}$ whereas $29.6 \%$ of BASIC members do not indicate any specific target. While $75 \%$ of all AOSIS participants indicate a minimum emission threshold not to exceed $55 \%$ of global carbon emissions, more than half of the UMBRELLA/EIG and the EU27 group favor a minimum requirement of at least $50 \%$ of global carbon emissions. Similarly to the AOSIS and

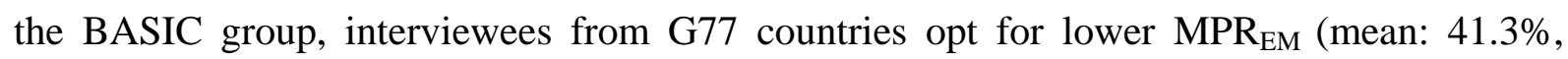
median: 50\%). These findings correspond to the proposals in the Kyoto negotiations where Chinese/G-77 delegates favored a threshold below 50\% of global carbon emissions.

Table 1: Descriptive results on minimum membership and emission thresholds

\begin{tabular}{|c|c|c|c|c|c|c|c|}
\hline \multicolumn{8}{|c|}{ Minimum number of UNFCCC member states } \\
\hline & Mean & $\begin{array}{l}\text { Std. } \\
\text { Dev. }\end{array}$ & Median & $\begin{array}{l}\text { No } \\
\text { requirement }\end{array}$ & $\begin{array}{l}0< \\
\mathrm{MPR}_{\mathrm{UN}} \\
\leq 55\end{array}$ & $\begin{array}{l}55< \\
\mathrm{MPR}_{\mathrm{UN}} \\
\leq 195\end{array}$ & $\mathrm{~N}$ \\
\hline & & & & & \% share & & \\
\hline All & 60.4 & 52.3 & 50 & 21.0 & 32.8 & 46.2 & 195 \\
\hline ANNEX B & 54.6 & 45.1 & 50 & 19.7 & 39.3 & 41.0 & 61 \\
\hline AOSIS & 81.9 & 54.6 & 100 & 9.1 & 27.3 & 63.6 & 11 \\
\hline BASIC & 60.0 & 59.1 & 50 & 39.1 & 13.0 & 47.9 & 23 \\
\hline EU27 & 57.0 & 45.0 & 50 & 18.6 & 41.9 & 39.5 & 43 \\
\hline UMBRELLA/EIG & 48.8 & 48.2 & 50 & 21.1 & 36.8 & 41.1 & 19 \\
\hline G77 & 60.8 & 52.8 & 50 & 18.6 & 33.7 & 47.7 & 86 \\
\hline \multicolumn{8}{|c|}{ Minimum share of global GHG emissions } \\
\hline & Mean & $\begin{array}{l}\text { Std. } \\
\text { Dev. }\end{array}$ & Median & $\begin{array}{l}\text { No } \\
\text { requirement }\end{array}$ & $\begin{array}{l}0 \%< \\
\mathrm{MPR}_{\mathrm{em}} \\
\leq 55 \% \\
\end{array}$ & $\begin{array}{l}55 \%< \\
M \mathrm{MR}_{\mathrm{em}} \\
\leq 100 \%\end{array}$ & $\mathrm{~N}$ \\
\hline & & & & & \% share & & \\
\hline All & 44.4 & 31.5 & 50 & 16.2 & 43.7 & 40.1 & 247 \\
\hline ANNEX B & 52.8 & 27.9 & 60 & 12.5 & 35.2 & 52.3 & 88 \\
\hline AOSIS & 37.8 & 25.3 & 41.5 & 8.3 & 75.0 & 16.7 & 12 \\
\hline BASIC & 31.0 & 32.6 & 20 & 29.6 & 44.4 & 25.9 & 27 \\
\hline EU27 & 47.5 & 30.5 & 51 & 18.6 & 33.9 & 47.5 & 59 \\
\hline UMBRELLA/EIG & 58.5 & 25.3 & 66 & 8.6 & 37.1 & 54.3 & 35 \\
\hline G77 & 41.3 & 32.6 & 50 & 16.2 & 46.5 & 37.3 & 99 \\
\hline
\end{tabular}

Individual perception of minimum membership requirements appears to be less diverse than emission thresholds. As expected, participants from AOSIS countries call for broad participation rates with an average of 82 of all 195 UNFCCC member states. In contrast, delegates from UMBRELLA/EIG countries indicate a mean minimum threshold of only 49 countries. The average proposal indicated from AOSIS participants in the survey has more than doubled in contrast to the Kyoto process where delegates from this region initially 
proposed 30 countries as their preferred threshold (UNFCCC 2000). 39.1\% of all participants from BASIC countries entirely reject a minimum membership requirement in a future climate agreement.

In the following, the discussion is based on the econometric results in order to analyze these first observations more in detail. I start with the discussion of the MPR $\mathrm{EM}_{\mathrm{EM}}$ and then turn to the $\mathrm{MPR}_{\mathrm{UN}}$. Table 2 reports result from the initial model specification, distinguishing between Annex B and Non-Annex B grouping only. In the Tobit models, the estimates can be interpreted as the marginal effect of the explanatory variable on the latent variable, that is on the values of $y_{i}$, ignoring the censoring In addition, I present marginal effects for the subpopulation for which $y_{i}$ is not at the tail limits in the Appendix.

There is evidence for a significant positive effect for Annex B countries on the assessment of $\mathrm{MPR}_{\mathrm{EM}}$ across all model specifications $(\mathrm{p}<0.01$, Table 2$)$. Delegates from countries with binding emission targets in the Kyoto Protocol opt for more ambitious minimum requirements than countries without any obligations in the agreement. After having controlled for the share of global $\mathrm{CO}_{2}$ emissions and the emission intensity with respect to GDP, the mean of the marginal effect for participants from ANNEX B countries amounts to 21.0 percentage points (Table 2, column 2) and is about half the size for those with $y_{i}$ between 0 and $z$ (Table A5). Current national GHG levels negatively affect preferences for high MPR $\mathrm{EM}_{\mathrm{EM}}$ : The higher the current emissions levels, the lower the indicated minimum emission thresholds (at least $\mathrm{p}<0.1$ ). After having controlled for Annex B participation, an increase in the share of global GHG emissions by the respective country by one percentage points lowers the preferred $\mathrm{MPR}_{\mathrm{EM}}$ by 1.4 percentage points. The effect remains in a similar range (1.3 percentage points) if emission intensity with respect to GDP is taken into account (Table 2, column 2). Again, the marginal effects for those with $y_{i}$ not at the boundary are almost half the size (Table A5). The negative impact of $\mathrm{CO}_{2}$ on the assessment of $\mathrm{MPR}_{\mathrm{EM}}$ also holds when controlling for per capita GDP which itself again positively influences minimum emission thresholds (at least $\mathrm{p}<0.05$, columns 3 and 6). These findings indicate that the developing effect appears to be the dominant driver. Fast growing emerging countries with high current emissions levels are more likely to oppose against high $\mathrm{MPR}_{\mathrm{EM}}$ than other countries. 
Table 2: Maximum likelihood estimates in Tobit models and interval regression, country groups: Annex B/non-Annex B

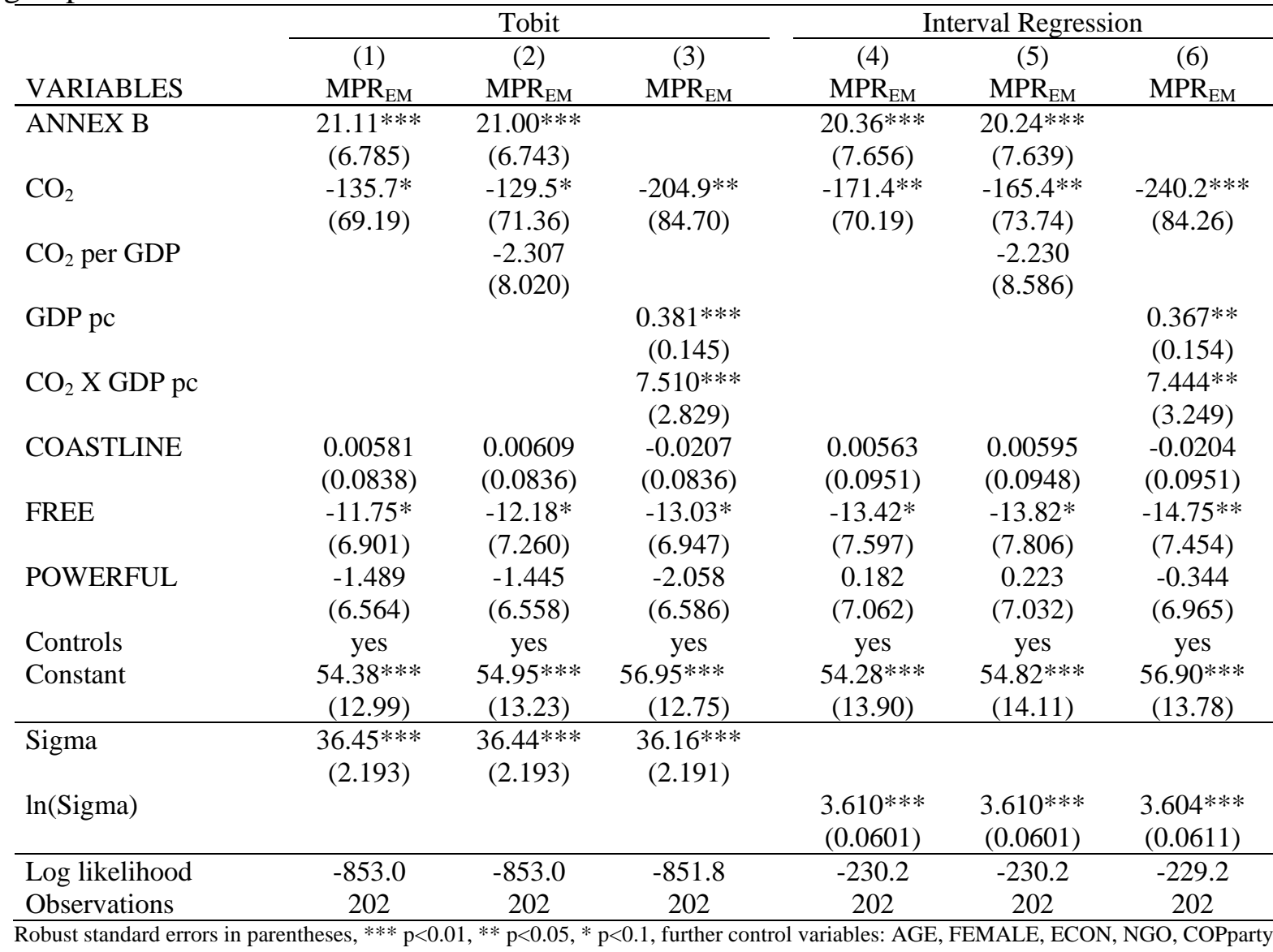

Table 3 reports estimated coefficients for the different UNFCCC party groupings and confirm the previous observations. Delegates from EU27 ( $\mathrm{p}<0.1$ but only in the Tobit models) and UMBRELLA/EIG countries $(\mathrm{p}<0.05)$ are more likely to indicate higher shares for minimum emissions requirements than participants from the G77 group. The share indicated by EU27 (UMBRELLA/EIG) negotiators is on average 17.1 (28.7) percentage points higher after having controlled for UNFCCC party groupings, the share of global $\mathrm{CO}_{2}$ emissions and the emission intensity with respect to GDP. ${ }^{8}$ In order to detect differences between the country groups beyond those to the base category I conduct a series of pairwise postestimation Wald tests after the fitted models on differences in estimated coefficients. This analysis reveals negotiators from UMBRELLA/EIG members to indicate significantly higher emissions thresholds than delegates from AOSIS $(\mathrm{p}<0.1)$ and from BASIC countries $(\mathrm{p}<0.1$ but only in the Tobit models). The negative impact of current emissions levels and the positive effect of per capita GDP remain significant in all model specifications. The average marginal effect for an increase in the share of global GHG emissions by the respective country is in the similar

8 A similar model specification, where I distinguish between EU27, UMBRELLA/EIG and other countries only reveals similar effects. In contrast to all other delegates, the indicated share of the EU27 (UMBRELLA/EIG) group is 12.4 (24.8) percentage points higher. 
range as before (1.4 percentage points) (Table 3, column 2). The effects of further explanatory variables only provide little additional insights. Both the length of the coastline, as an indicator for vulnerability to climate change, and the perceived bargaining power do not alter the decision towards $\mathrm{MPR}_{\mathrm{EM}}$ in the sample significantly. Countries with the highest freedom status considering both political rights and civil liberty appear to opt for lower $\mathrm{MPR}_{\mathrm{EM}}$ but this effect becomes insignificant as soon as the different party groupings are included in the analysis. Summarizing these findings, delegates from industrialized countries rather vote for an emission threshold that requires all major current emitters to participate in a future climate deal. In contrast, delegates from emerging countries suggest lower minimum requirements which might allow for a climate treaty formed by developed countries only. This latter position may be driven by the frequent call for an equal right for development. It reflects current challenges of the Durban Platform on ensuring participation and commitment to ambitious emissions reductions in a future climate deal.

Table 3: Maximum likelihood estimates in Tobit models and interval regression, country groups: UNFCCC party groupings

\begin{tabular}{|c|c|c|c|c|}
\hline \multirow[b]{3}{*}{ VARIABLES } & \multicolumn{2}{|c|}{ Tobit } & \multicolumn{2}{|c|}{ Intervall Regression } \\
\hline & (1) & (2) & (3) & (4) \\
\hline & $\mathrm{MPR}_{\mathrm{EM}}$ & $\mathrm{MPR}_{\mathrm{EM}}$ & $\mathrm{MPR}_{\mathrm{EM}}$ & $\mathrm{MPR}_{\mathrm{EM}}$ \\
\hline \multirow[t]{2}{*}{ AOSIS } & 8.347 & 8.969 & 0.170 & 0.746 \\
\hline & (11.64) & (11.61) & (12.35) & $(12.22)$ \\
\hline \multirow[t]{2}{*}{ BASIC } & 7.001 & 8.096 & 6.525 & 7.520 \\
\hline & $(12.16)$ & $(12.51)$ & $(13.06)$ & $(13.34)$ \\
\hline \multirow[t]{2}{*}{ EU27 } & $16.94^{*}$ & 17.09* & 14.00 & 14.14 \\
\hline & $(9.465)$ & $(9.464)$ & $(10.76)$ & (10.73) \\
\hline \multirow[t]{2}{*}{ UMBRELLA/EIG } & $28.32 * * *$ & $28.71^{* * * *}$ & $21.70 * *$ & $22.05 * *$ \\
\hline & $(8.074)$ & $(8.161)$ & $(9.616)$ & $(9.623)$ \\
\hline \multirow[t]{2}{*}{$\mathrm{CO}_{2}$} & $-150.6 *$ & $-143.1^{*}$ & $-183.7^{* *}$ & $-176.8^{* *}$ \\
\hline & (76.35) & (76.15) & $(80.04)$ & $(80.71)$ \\
\hline \multirow[t]{2}{*}{$\mathrm{CO}_{2}$ per GDP } & & -3.979 & & -3.630 \\
\hline & & $(8.627)$ & & $(8.932)$ \\
\hline \multirow[t]{2}{*}{ COASTLINE } & -0.0320 & -0.0323 & -0.0129 & -0.0131 \\
\hline & $(0.0916)$ & $(0.0912)$ & $(0.105)$ & $(0.104)$ \\
\hline \multirow[t]{2}{*}{ FREE } & -11.04 & -12.15 & -10.55 & -11.56 \\
\hline & (7.653) & $(8.212)$ & (8.823) & (9.162) \\
\hline \multirow[t]{2}{*}{ POWERFUL } & -3.169 & -3.268 & -2.074 & -2.168 \\
\hline & (6.813) & (6.775) & (7.352) & (7.327) \\
\hline \multicolumn{5}{|l|}{ Controls } \\
\hline \multirow[t]{2}{*}{ Constant } & $49.98 * * *$ & $50.91 * * *$ & $50.97 * * *$ & $51.80 * * *$ \\
\hline & $(13.00)$ & (13.21) & $(13.90)$ & $(14.12)$ \\
\hline \multirow[t]{2}{*}{ Sigma } & $36.38 * * *$ & $36.37 * * *$ & & \\
\hline & (2.186) & $(2.185)$ & & \\
\hline \multirow[t]{2}{*}{ ln(Sigma) } & & & $3.615^{* * *}$ & $3.615 * * *$ \\
\hline & & & $(0.0600)$ & $(0.0600)$ \\
\hline Log likelihood & -852.8 & -852.7 & -231.1 & -231.1 \\
\hline Observations & 202 & 202 & 202 & 202 \\
\hline
\end{tabular}

Following the descriptive findings, the econometric results of the minimum membership requirements reveals that Annex B countries call for smaller participation rates at least $\mathrm{p}<0.1$ 
but only in the Tobit models, Table 4). After having controlled for the share of global $\mathrm{CO}_{2}$ emissions and the emission intensity with respect to GDP, the mean of the marginal effect for participants from Annex B countries suggest that those negotiators prefer a $\mathrm{MPR}_{\mathrm{UN}}$ containing about 27 fewer countries than other delegates (Table 4, column 2). In line with the initial hypothesis, there is evidence that delegates perceiving their bargaining power to be low tend to vote for higher participation rules (Table 4, column 2 and 5). Further support for this relationship can be derived from the analysis of the different country groups (Table 5). The estimated coefficient for AOSIS is highest in all model specifications and differs significantly from those obtained for EU27 (at least $\mathrm{p}<0.1$, postestimation test) and UMBRELLA/EIG ( $<<0.1$, but only for postestimation tests of the Tobit models). Small countries may therefore perceive a minimum membership threshold as an instrument to strengthen their bargaining position in future negotiations. In contrast, high developed countries set a lower threshold to allow for smaller agreements $(\mathrm{p}<0.05$, Table 4 and Table 5, column 6). Again, the effects for vulnerability and freedom status remain insignificant in the sample.

Table 4: Maximum likelihood estimates in Tobit models and interval regression, country groups: Annex B/non-Annex B

\begin{tabular}{|c|c|c|c|c|c|c|}
\hline \multirow[b]{3}{*}{ VARIABLES } & \multicolumn{3}{|c|}{ Tobit } & \multicolumn{3}{|c|}{ Interval Regression } \\
\hline & (1) & $(2)$ & (3) & (4) & (5) & (6) \\
\hline & $\mathrm{MPR}_{\mathrm{UN}}$ & $\mathrm{MPR}_{\mathrm{UN}}$ & $\mathrm{MPR}_{\mathrm{UN}}$ & $\mathrm{MPR}_{\mathrm{UN}}$ & $\mathrm{MPR}_{\mathrm{UN}}$ & $\mathrm{MPR}_{\mathrm{UN}}$ \\
\hline \multirow[t]{2}{*}{ ANNEX B } & $-27.17 *$ & $-27.32 *$ & & -18.17 & -18.89 & \\
\hline & (14.32) & (14.15) & & $(14.20)$ & (14.14) & \\
\hline \multirow[t]{2}{*}{$\mathrm{CO}_{2}$} & -70.08 & -61.75 & -158.5 & -26.91 & 16.17 & -155.1 \\
\hline & (123.5) & (130.9) & (164.4) & (138.9) & $(142.2)$ & (172.3) \\
\hline \multirow{2}{*}{$\mathrm{CO}_{2}$ per GDP } & & -2.965 & & & -15.18 & \\
\hline & & (20.57) & & & (19.01) & \\
\hline \multirow[t]{2}{*}{ GDP pc } & & & -0.298 & & & -0.335 \\
\hline & & & $(0.348)$ & & & $(0.318)$ \\
\hline \multirow[t]{2}{*}{$\mathrm{CO}_{2} \mathrm{X}$ GDP pc } & & & 5.342 & & & $10.72 * *$ \\
\hline & & & $(4.225)$ & & & $(4.622)$ \\
\hline \multirow[t]{2}{*}{ COASTLINE } & -0.0855 & -0.0862 & -0.139 & 0.0306 & 0.0284 & -0.00772 \\
\hline & $(0.209)$ & $(0.208)$ & $(0.219)$ & $(0.276)$ & $(0.273)$ & $(0.282)$ \\
\hline \multirow[t]{2}{*}{ FREE } & 7.773 & 7.316 & -2.804 & 2.027 & -0.443 & -4.663 \\
\hline & $(14.26)$ & $(15.50)$ & $(14.90)$ & $(14.20)$ & $(15.44)$ & $(14.57)$ \\
\hline \multirow[t]{2}{*}{ POWERFUL } & $-21.56 *$ & $-21.68 *$ & -14.70 & $-21.34 *$ & $-21.80 *$ & -15.74 \\
\hline & $(12.64)$ & $(12.62)$ & $(12.27)$ & (12.63) & (12.58) & $(12.26)$ \\
\hline Controls & yes & yes & yes & yes & yes & yes \\
\hline \multirow[t]{2}{*}{ Constant } & 4.656 & 5.763 & 10.39 & -2.597 & 2.754 & 4.509 \\
\hline & $(27.94)$ & $(28.75)$ & (29.13) & $(27.37)$ & (28.39) & $(27.82)$ \\
\hline \multirow[t]{2}{*}{ Sigma } & $64.75 * * *$ & $64.74 * * *$ & $65.45 * * *$ & & & \\
\hline & $(4.421)$ & $(4.431)$ & $(4.420)$ & & & \\
\hline \multirow[t]{2}{*}{$\ln ($ Sigma $)$} & & & & $4.089 * * *$ & $4.087 * * *$ & $4.084 * * *$ \\
\hline & & & & $(0.0845)$ & $(0.0847)$ & $(0.0852)$ \\
\hline Log likelihood & -676.2 & -676.2 & -677.1 & -155.9 & -155.7 & -155.3 \\
\hline Observations & 149 & 149 & 149 & 149 & 149 & 149 \\
\hline
\end{tabular}


Table 5: Maximum likelihood estimates in Tobit models and interval regression, dependent variable: minimum emissions requirements $\left(\mathrm{MPR}_{\mathrm{UN}}\right)$, country groups: UNFCCC party

\begin{tabular}{|c|c|c|c|c|}
\hline \multicolumn{5}{|c|}{ groupings } \\
\hline & \multicolumn{2}{|c|}{ Tobit } & \multicolumn{2}{|c|}{ Intervall Regression } \\
\hline & (1) & (2) & (3) & (4) \\
\hline \multirow{3}{*}{$\begin{array}{l}\text { VARIABLES } \\
\text { AOSIS }\end{array}$} & $\mathrm{MPR}_{\mathrm{UN}}$ & $\mathrm{MPR}_{\mathrm{UN}}$ & $\mathrm{MPR}_{\mathrm{UN}}$ & $\mathrm{MPR}_{\mathrm{UN}}$ \\
\hline & 25.04 & 25.96 & 21.26 & 23.55 \\
\hline & (23.19) & $(23.16)$ & $(23.24)$ & (23.09) \\
\hline \multirow[t]{2}{*}{ BASIC } & 25.09 & 26.78 & 14.97 & 19.13 \\
\hline & $(25.41)$ & $(25.20)$ & (24.59) & $(24.72)$ \\
\hline \multirow[t]{2}{*}{ EU27 } & -13.81 & -13.88 & -12.01 & -12.14 \\
\hline & (18.11) & $(18.12)$ & $(18.43)$ & $(18.46)$ \\
\hline \multirow[t]{2}{*}{ UMBRELLA/EIG } & -8.389 & -8.115 & 0.596 & 1.668 \\
\hline & (19.57) & (19.66) & (20.67) & (20.43) \\
\hline \multirow[t]{2}{*}{$\mathrm{CO}_{2}$} & -139.0 & -118.3 & -71.54 & -24.49 \\
\hline & (137.3) & $(144.1)$ & $(152.6)$ & (153.1) \\
\hline \multirow{2}{*}{$\mathrm{CO}_{2}$ per GDP } & & -8.845 & & -20.33 \\
\hline & & $(20.10)$ & & (19.54) \\
\hline \multicolumn{5}{|l|}{ GDP pc } \\
\hline \multicolumn{5}{|l|}{$\mathrm{CO}_{2} \mathrm{X}$ GDP pc } \\
\hline \multirow[t]{2}{*}{ COASTLINE } & -0.119 & -0.122 & -0.0395 & -0.0479 \\
\hline & $(0.237)$ & $(0.236)$ & $(0.301)$ & $(0.296)$ \\
\hline \multirow[t]{2}{*}{ FREE } & -5.463 & -7.324 & -6.055 & -10.52 \\
\hline & $(15.81)$ & (16.98) & (16.19) & $(17.52)$ \\
\hline \multirow[t]{2}{*}{ POWERFUL } & $-25.28 *$ & $-26.03 *$ & $-23.20 *$ & $-24.79 *$ \\
\hline & $(14.12)$ & (14.01) & (13.44) & $(13.40)$ \\
\hline Controls & yes & yes & yes & yes \\
\hline \multirow[t]{2}{*}{ Constant } & 4.937 & 8.113 & -2.518 & 4.354 \\
\hline & $(27.48)$ & $(28.35)$ & $(27.16)$ & $(28.20)$ \\
\hline \multirow[t]{2}{*}{ Sigma } & $64.37 * * *$ & $64.31 * * *$ & & \\
\hline & (4.359) & (4.378) & & \\
\hline \multirow[t]{2}{*}{$\ln ($ Sigma $)$} & & & $4.085 * * *$ & $4.080 * * *$ \\
\hline & & & $(0.0846)$ & $(0.0850)$ \\
\hline Log likelihood & -675.6 & -675.5 & -155.4 & -155.0 \\
\hline Observations & 149 & 149 & 149 & 149 \\
\hline
\end{tabular}

\section{Conclusions}

To overcome the social dilemma situation in current international climate policy, any adequate institutional design has to address participation and commitment of sufficient (key) players. Recent contributions to the theoretical and experimental literature suggest minimum participation requirements to reduce free-riding incentives and to facilitate cooperation (or at least coordination) at the extensive margin of a future climate treaty. Minimum participation rules are a common institutional design in international environmental agreements: Rutz (2001) studied 122 IEA treaty texts and only identifies two agreements without any minimum participation rules. While stricter requirements may broaden participation and therefore lead to more cost-effective agreements, they are also more susceptible to coordination failures and may increase veto power for non-signatories. The Kyoto Protocol entered into force eight years after it was negotiated in 1997 since the second part of its double trigger (at least 55 
parties of UNFCCC member states that include at least 55\% of total Annex I carbon emissions in 1990) was hardly to be met after Australia and the USA declined to join the treaty such that Russia was decisive for the treaty to enter into force.

Based on a dataset from a world-wide survey among delegates in international climate negotiations (COP-16 in Cancún in 2010 and COP-17 in Durban in 2011), I assessed individual preferences for different minimum participation rules among different groups of countries. Summarizing the empirical findings, discussions on MPRs in ongoing climate negotiations are expected to remain controversial. That holds particularly with respect to a minimum emission threshold. Small countries with low bargaining power in international climate negotiations call for ambitious membership requirements which may help to strengthen their position in future negotiations. High developed countries set lower minimum membership requirements but opt for emission thresholds that require all major current emitters to participate in a future climate deal. They may therefore push forward the idea of having a small sub-agreement among the largest emitters only (“carbon clubs”). In contrast, delegates from countries in transition suggest lower emissions thresholds which would allow them to stay away from a climate treaty formed by developed countries only. This latter position may be driven by the frequent call for equal rights for development and reflect the current challenges on ensuring participation and commitment to ambitious emissions reductions in future climate negotiations. 


\section{Literature}

Aldy JE, Stavins RN (2012), Climate Change Negotiators Create an Opportunity for Scholars, Science 337, 1043-1044.

Barrett S (1994), Self Enforcing International Enviromental Agreements, Oxford Economic Papers 46, 878-894.

Barrett S (1998a), On the Theory and Diplomacy of Environmental, Environmental and Resource Economics 11, 317-333.

Barrett S (1998b), Political Economy of the Kyoto Protocol, Oxford Review of Economic Policy 14, 20-39.

Barrett S (1999), A Theory of Full International Cooperation, Journal of Theoretical Politics 11, 519-541.

Barrett S (2003), Environment \& Statecraft: The Strategy of Environmental Treaty-Making. Oxford University Press, Oxford, UK.

Barrett S, Graddy K (2000), Freedom, growth, and the environment, Environment and Development Economics 5, 433-456.

Barrett S, Stavins R (2003), Increasing Participation and Compliance in International Climate Change Agreements, International Environmental Agreements: Politics, Law and Economics 3, 349-376.

Bernard A, Paltsev S, Reilly JM, Vielle M, Viguier L (2003), Russia's Role in the Kyoto Protocol, MIT Joint Program on the Science and Policy of Global Climat Change Report No. 98.

Beron KJ, Murdoch JC, Vijverberg WPM (2003), Why cooperate? Public goods, economic power, and the Montreal protocol, The Review of Economics and Statistics 85, 286-297.

Black J, Levi MD, de Meza D (1993), Minimum Participation for Tackling the Greenhouse Effect, Economica 60, 281-293.

Böhringer C, Vogt C (2003), Economic and environmental impacts of the Kyoto Protocol, The Canadian Journal of Economics 36, 475-494.

Böhringer C, Vogt C (2004), The dismantling of a breakthrough: the Kyoto Protocol as symbolic policy, European Journal of Political Economy 20, 597-617.

Carraro C, Marchiori C, Oreffice S (2009), Endogenous Minimum Participation in International Environmental Treaties, Environmental and Resource Economics 42, 411425.

Carraro C, Siniscalco D (1993), Strategies for the international of the environment, Journal of Public Economics 52, 309-328.

CIA (Central Intelligence Agency) (2014), The World Factbook: Data on coastline per country, https:/www.cia.gov/library/publications/the-world-factbook/fields/2060.html, access on November 28, 2014.

Congleton RD (1992), Political Institutions and Pollution Control, Review of Economics and Statistics 124, 412-421.

Courtois P, Haeringer G (2012), Environmental cooperation: ratifying second-best agreements, Public Choice 151, 565-584.

Cox NJ (2009), Speaking Stata: Creating and varying box plots Box plots, The Stata Jorunal 478-496.

Edenhofer O, Flachsland C, Stavins R, Stowe R (2013), Identifying Options for a New International Climate Regime Arising from the Durban Platform for Enhanced Action, Policy Brief, Harvard Project on Climate Agreements, Belfer Center for Science and International Affairs, Harvard Kennedy School and Mercator Research Institute on Global Commons and Climate Change. 
Finus M, Maus S (2008), Modesty may pay!, Journal of Public Economic Theory 10, 801826.

Freedom House (2014), Freedom in the World 2014, https://freedomhouse.org/sites/default/files/FIW2014\%20Booklet.pdf, access on November 28, 2014.

Gerber A, Neitzel J, Wichardt PC (2013), Minimum participation rules for the provision of public goods, European Economic Review 64, 209-222.

Harstad B (2006), Flexible Integration? Mandatory and Minimum Participation Rules, Scandinavian Journal of Economics 108, 683-702.

Hjerpe M, Löfgren Å, Linnér B, Hennlock M (2011), Common ground for effort sharing ? Preferred principles for distributing climate mitigation efforts, Working Paper in Economics No. 491, University of Gothenburg.

Hoel M (1992), International Environment Conventions : The Case of Uniform Reductions of Emissions, Environmental and Resource Economics 2, 141-159.

IPCC (Intergovernmental Panel on Climate Change) (2013), Summary for Policymakers, in: Stocker, T.F., Qin, D., Plattner, G.-K., Tignor, M., Allen, S.K., Boschung, J., Nauels, A., Xia, Y., Bex, V., Midgley, P.M. (Eds.), Climate Change 2013: Contribution of Working Goup I to the Fifth Assessment Report of the Intergovernmental Panel on Climate Change. Cambridge University Press, Cambridge, UK and New York, USA.

Kesternich M, Löschel A, Ziegler A (2014), Negotiating Weights for Burden Sharing Rules among Heterogeneous Parties: Empirical Evidence from a Survey among Delegates in International Climate Negotiations, ZEW Discussion Paper Series No. 14-031.

Köke S, Lange A (2013), Negotiating Environmental Agreements under Ratification Uncertainty, mimeo.

Kosfeld M, Okada A, Riedl A (2009), Institution Formation in Public Goods Games, American Economic Review 99, 1335-1355.

Lange A, Löschel A, Vogt C, Ziegler A (2010), On the self-interested use of equity in international climate negotiations, European Economic Review 54, 359-375.

Lange A, Vogt C (2003), Cooperation in international environmental negotiations due to a preference for equity, Journal of Public Economics 87, 2049-2067.

Lange A, Vogt C, Ziegler A (2007), On the importance of equity in international climate policy: An empirical analysis, Energy Economics 29, 545-562.

McEvoy DM, Cherry TL, Stranlund JK (2014), Endogenous Minimum Participation in International Environmental Agreements: An Experimental Analysis, Environmental and Resource Economics.

Meulemann M (2014), Architechtures for International Climate Agreements: An Empirical Asessment, mimeo.

Meulemann M, Ziegler A (2013), The Role of Burden Sharing Rules in international climate negotiations, mimeo.

Neumayer E (2002), Environmental Commitment? A Cross-Country Analysis, Journal of Peace Research 39, 139-164.

Olivier J, Janssens-Maenhout G, Muntean M, Peters J (2013), Trends in global CO2 emissions - 2013 report, http://edgar.jrc.ec.europa.eu/news_docs/pbl-2013-trends-inglobal-co2-emissions-2013-report-1148.pdf, access on May 9, 2014.

Olsson M, Atteridge A, Hallding K, Hellberg J (2010), Together Alone? Brazil, South Africa, India, China ( BASIC ) and the Climate Change Conundrum, Stockholm Environment Institute Policy Brief.

Paltsev S V (2000), The Kyoto Protocol: “ Hot air ” for Russia?, University of Colorado at Boulder Working Papers in Economics No. 00-09. 
Rutz S (2001), Minimum Participation Rules and the Effectiveness of Multilateral Environmental Agreements, ETH Zurich WIF Working Paper Series, Workin Paper Series.

The World Bank (2014), Data on GDP 2011 (current US\$), http://data.worldbank.org/indicator/NY.GDP.MKTP.CD, access on May 5, 2014.

UNFCCC (United Nations Framework Convention on Climate Change) (1998), Kyoto Protocol to the United Nations Framework Convention on Climate Change.

UNFCCC (United Nations Framework Convention on Climate Change) (2000), Tracing the origins of the Kyoto Protocol: An article-by-article textual history, FCCC/TP/2000/2.

UNFCCC (United Nations Framework Convention on Climate Change) (2002), Kyoto Protocol Receives 100th Ratification, Press Release.

UNFCCC (United Nations Framework Convention on Climate Change) (2012), Establishment of an Ad Hoc Working Group on the Durban Platform for Enhanced Action, Decision 1/CP.17, FCCC/CP/2011/9/Add.1.

UNFCCC (United Nations Framework Convention on Climate Change) (2013), Party groupings, http://unfccc.int/parties_and_observers/parties/negotiating_groups/items/2714.php, access on September 23, 2014.

UNFCCC (United Nations Framework Convention on Climate Change) (2014), Lima call for climate action, Decision -/CP.20.

Victor DG (2011), Global Warming Gridlock: Creating More Effective Strategies for Protecting the Planet. Cambridge University Press, New York, USA.

Weikard H-P, Wangler L, Freytag A (2012), Minimum Participation Rules with Heterogeneous Countries, mimeo.

Wooldridge JM (2002), Econometric Analysis of Cross Section and Panel Data. The MIT Press, Cambridge, Massachusetts, US, London, UK. 


\section{Appendix}

Table A1: Overview on party groupings

\begin{tabular}{|c|c|}
\hline Description & Shortcut \\
\hline 43 member states of the Alliance of Small Island States & AOSIS \\
\hline Brazil, South Africa, India, China & BASIC \\
\hline 27 member states of the European Union & EU27 \\
\hline $\begin{array}{l}\text { Australia, Canada, Japan, Liechtenstein, Mexico, Monaco, New Zealand, Norway, } \\
\text { Republic of Korea, Russia, Switzerland, Ukraine, USA }\end{array}$ & UMBRELLA/EIG \\
\hline 133 member states of the G77 group without AOSIS and BASIC members & G77 \\
\hline
\end{tabular}

Table A2: Summary statistics of the dependent variables

\begin{tabular}{|c|c|c|c|c|}
\hline Categories & $\mathrm{MPR}_{\mathrm{UN}}$ & $\%$ & $\mathrm{MPR}_{\mathrm{EM}}$ & $\%$ \\
\hline$a_{1}$ & $\leq 0$ (left-censored) & 21.03 & $\leq \quad 0$ (left-censored) & 16.19 \\
\hline$a_{2}$ & $>\quad 0$ until $\leq 55$ & 32.82 & $>\quad 0$ until $\leq 55$ & 43.72 \\
\hline$a_{3}$ & $>55$ until $<195$ & 45.64 & $>55$ until $<100$ & 36.44 \\
\hline$a_{4}$ & $\geq 195$ (right-censored) & 0.51 & $\geq 100$ (right-censored) & 3.64 \\
\hline TOTAL & & $\begin{array}{l}100.00 \\
(n=195)\end{array}$ & & $\begin{array}{l}100.00 \\
(\mathrm{n}=247)\end{array}$ \\
\hline
\end{tabular}

Table A3: Data on GDP, population and carbon emissions for respective countries and regions

\begin{tabular}{lrrrrr}
\hline & $\begin{array}{r}\text { GDP } 2011 \\
\text { (in } \begin{array}{r}\text { current } \\
\text { Billion US\$) }\end{array}\end{array}$ & $\begin{array}{l}\text { Share } \\
\text { global } \\
\text { (in \%) }\end{array}$ & $\begin{array}{r}\text { of } \\
\text { GDP }\end{array}$ & $\begin{array}{l}\mathrm{CO}_{2} \\
\text { enissions } \\
\text { 2011 } \\
\text { (in Mtons) }\end{array}$ & $\begin{array}{l}\text { Share } \\
\text { global } \\
\text { emissions } \\
\text { (in \%) }\end{array}$ \\
\hline WORLD & $\mathbf{7 1 , 0 2 8 . 5}$ & $\mathbf{1 0 0 . 0}$ & $\begin{array}{r}\text { of } \\
\mathrm{CO}_{2}\end{array}$ \\
AOSIS & $\mathbf{4 7 9 . 1}$ & $\mathbf{0 . 7}$ & $\mathbf{1 8 . 3}$ & $\mathbf{1 0 0 . 0}$ \\
BASIC & $\mathbf{1 2 , 0 8 0 . 5}$ & $\mathbf{1 7 . 0}$ & $\mathbf{1 2 , 1 6 0 . 2}$ & $\mathbf{0 . 1}$ \\
Brazil & $2,476.7$ & 3.5 & 447.2 & 1.3 \\
South Africa & 401.8 & 0.6 & 327.1 & 1.0 \\
India & $1,880.1$ & 2.6 & $1,838.4$ & 5.4 \\
China & $7,321.9$ & 10.3 & $9,547.5$ & 28.1 \\
EU27 & $\mathbf{1 7 , 6 1 4 . 6}$ & $\mathbf{2 4 . 8}$ & $3,787.1$ & $\mathbf{1 1 . 1}$ \\
France & $2,779.7$ & 3.9 & 369.4 & 1.1 \\
Germany & $3,624.9$ & 5.1 & 794.7 & 2.3 \\
United Kingdom & $2,478.9$ & 3.5 & 471.3 & 1.4 \\
UMBRELLA/EIG & $\mathbf{3 0 , 2 0 8 . 7}$ & $\mathbf{4 2 . 5}$ & $\mathbf{1 0 , 4 0 1 . 7}$ & $\mathbf{3 0 . 6}$ \\
Australia & $1,386.9$ & 2.0 & 440.3 & 1.3 \\
Canada & $1,737.0$ & 2.4 & 563.2 & 1.7 \\
Japan & $5,896.8$ & 8.3 & $1,244.3$ & 3.7 \\
Mexiko & $1,159.9$ & 1.6 & 468.8 & 1.4 \\
Republic of Korea & $1,114.5$ & 1.6 & 69.8 & 0.2 \\
Russia & $1,899.1$ & 2.7 & $1,780.4$ & 5.2 \\
USA & $15,533.8$ & 21.9 & $5,392.2$ & 15.9 \\
G77 & $\mathbf{8 , 3 4 7 . 8}$ & $\mathbf{1 1 . 8}$ & $\mathbf{4 , 7 6 3 . 8}$ & $\mathbf{1 4 . 0}$ \\
\hline
\end{tabular}

Note: Data on GDP is taken from the the World Bank (2014) and data on CO2 emissions is obtained from Emission Database for Global Atmospheric Research (EDGAR) (Olivier et al. 2013). 
Table A4: Descriptive information on explanatory variables

\begin{tabular}{|c|c|c|c|}
\hline Variable & & $\begin{array}{l}\mathrm{MPR}_{\mathrm{UN}} \\
(\mathrm{n}=195)\end{array}$ & $\begin{array}{l}M^{M P R} R_{E M} \\
(n=247)\end{array}$ \\
\hline & & $\%$ & $\%$ \\
\hline ANNEX B & $\begin{array}{l}=1 \text {, if stated home country is a member of the ANNEX B group in } \\
\text { the Kyoto Protocol }\end{array}$ & 31.3 & 35.6 \\
\hline $\begin{array}{l}\text { AOSIS } \\
\text { BASIC } \\
\text { EU27 } \\
\text { UMBRELLA/EIG }\end{array}$ & $\begin{array}{l}=1, \text { if stated home country is AOSIS member } \\
=1, \text { if stated home country is BASIC member } \\
=1, \text { if stated home country is EU27 member } \\
=1, \text { if stated home country is UMBRELLA/EIG member } \\
\text { No information for } 5 \text { (4) observations }\end{array}$ & $\begin{array}{r}5.6 \\
11.8 \\
22.1 \\
9.7 \\
2.6\end{array}$ & $\begin{array}{r}4.9 \\
10.9 \\
23.9 \\
13.8 \\
1.6 \\
\end{array}$ \\
\hline $\mathrm{CO}_{2} 2011$ & $\begin{array}{l}\text { share of global } \mathrm{CO}_{2} \text { emissions } \\
\text { Mean: } 0.02(0.01) \\
\text { Min: } 2.94 \mathrm{e}-08 \text { (Nauru), Max: } 0.28 \text { (China) } \\
\text { No information for } 7 \text { (8) observations }\end{array}$ & 3.6 & 3.2 \\
\hline GDP pc 2011 & $\begin{array}{l}\text { gross domestic product per capita in } 2011 \text { in 1,000 current USD } \\
\text { Mean: } 18.8 \\
\text { Min: } 0.25 \text { (Congo), Max: } 111.8 \text { (Luxembourg) } \\
\text { No information for } 11 \text { (8) observations }\end{array}$ & 5.6 & 3.3 \\
\hline COASTLINE & $\begin{array}{l}\text { coastline of home country in1,000 km } \\
\text { Mean: } 6.6 \text { (9.4) } \\
\text { Min: 0, Max: } 202.1 \text { (Canada) } \\
\text { No information for } 7 \text { (7) observations }\end{array}$ & 5.1 & 2.8 \\
\hline FREE & $\begin{array}{l}=1 \text {, if stated home country is categorized as free in terms of the } \\
\text { country's political rights and civil liberties }\end{array}$ & 53.8 & 57.1 \\
\hline POWERFUL & $\begin{array}{l}=1 \text {, if respondent assesses the home countries' bargaining position } \\
\text { in current climate negotiations to be "very powerful" or "powerful” } \\
\text { No information for } 19(21)\end{array}$ & $\begin{array}{r}27.8 \\
9.7\end{array}$ & $\begin{array}{r}25.2 \\
8.5\end{array}$ \\
\hline AGE & $\begin{array}{l}\text { in years } \\
\text { Mean: } 46 \text { Min: } 23 \text { Max: } 74 \text { (for MPR } \mathrm{UN}_{\text {}} \text { ) } \\
\text { Mean: } 45 \text { Min: } 23 \text { Max: } 76 \text { (for MPR } \text { EM }) \\
\text { No information for } 4 \text { (3) observations }\end{array}$ & 2.1 & 1.2 \\
\hline FEMALE & $\begin{array}{l}=1 \text {, if respondent is a woman } \\
\text { No information for } 2 \text { (2) observations }\end{array}$ & $\begin{array}{r}26.9 \\
1.0\end{array}$ & $\begin{array}{r}24.5 \\
0.8\end{array}$ \\
\hline ECON & $\begin{array}{l}=1 \text {, if individual's highest degree is obtained in the field of } \\
\text { economics or business administration } \\
\text { No information for } 10 \text { (9) observations }\end{array}$ & $\begin{array}{r}18.4 \\
5.1\end{array}$ & $\begin{array}{r}18.5 \\
3.6\end{array}$ \\
\hline NGO & $\begin{array}{l}=1, \text { if the respondent works for an NGO } \\
\text { No information for } 8 \text { (8) observations }\end{array}$ & $\begin{array}{r}12.3 \\
4.1\end{array}$ & $\begin{array}{r}13.0 \\
3.2\end{array}$ \\
\hline COPparty & $\begin{array}{l}=1 \text {, if the respondent was a delegation member in COP-16 and/or } \\
\text { COP-17 } \\
\text { No information for } 6 \text { (6) observations }\end{array}$ & $\begin{array}{r}80.4 \\
3.1\end{array}$ & $\begin{array}{r}80.9 \\
2.4\end{array}$ \\
\hline
\end{tabular}


Table A5: Maximum likelihood estimates in Tobit models (marginal effects of the truncated expected value), country groups: Annex B/non-Annex B

\begin{tabular}{|c|c|c|c|}
\hline \multirow[b]{2}{*}{ VARIABLES } & \multicolumn{3}{|c|}{ Tobit } \\
\hline & $\begin{array}{c}(1) \\
\mathrm{MPR}_{\mathrm{EM}}\end{array}$ & $\begin{array}{c}(2) \\
\mathrm{MPR}_{\mathrm{EM}}\end{array}$ & $\begin{array}{c}(3) \\
\mathrm{MPR}_{\mathrm{EM}}\end{array}$ \\
\hline ANNEX B & $\begin{array}{c}10.02 * * * \\
(3.320)\end{array}$ & $\begin{array}{c}9.963 * * * \\
(3.304)\end{array}$ & \\
\hline $\mathrm{CO}_{2}$ & $\begin{array}{c}-64.07 * * \\
(32.45)\end{array}$ & $\begin{array}{l}-61.14^{*} \\
(33.50)\end{array}$ & $\begin{array}{l}-20.80 \\
(26.64)\end{array}$ \\
\hline $\mathrm{CO}_{2}$ per GDP & & $\begin{array}{c}-1.090 \\
(3.788)\end{array}$ & \\
\hline GDP pc & & & $\begin{array}{c}0.226 * * * \\
(0.0699)\end{array}$ \\
\hline COASTLINE & $\begin{array}{l}0.00274 \\
(0.0396)\end{array}$ & $\begin{array}{l}0.00287 \\
(0.0395)\end{array}$ & $\begin{array}{l}-0.00986 \\
(0.0398)\end{array}$ \\
\hline FREE & $\begin{array}{l}-5.512^{*} \\
(3.169)\end{array}$ & $\begin{array}{l}-5.709^{*} \\
(3.333)\end{array}$ & $\begin{array}{l}-6.159^{*} \\
(3.226)\end{array}$ \\
\hline POWERFUL & -0.703 & -0.682 & -0.980 \\
\hline Controls & yes & yes & yes \\
\hline Observations & 202 & 202 & 202 \\
\hline
\end{tabular}

Table A6: Maximum likelihood estimates in Tobit models (marginal effects of the truncated expected value), country groups: UNFCCC party groupings

\begin{tabular}{|c|c|c|}
\hline VARIABLES & $\begin{array}{c}(1) \\
\mathrm{MPR}_{\mathrm{EM}}\end{array}$ & $\begin{array}{c}(2) \\
M^{\prime} R_{E M}\end{array}$ \\
\hline AOSIS & $\begin{array}{c}3.966 \\
(5.526)\end{array}$ & $\begin{array}{c}4.263 \\
(5.507)\end{array}$ \\
\hline BASIC & $\begin{array}{c}3.314 \\
(5.736)\end{array}$ & $\begin{array}{c}3.832 \\
(5.893)\end{array}$ \\
\hline EU27 & $\begin{array}{l}8.005^{*} \\
(4.504)\end{array}$ & $\begin{array}{l}8.079^{*} \\
(4.503)\end{array}$ \\
\hline UMBRELLA/EIG & $\begin{array}{c}13.40 * * * \\
(3.769)\end{array}$ & $\begin{array}{c}13.58 * * * \\
(3.803)\end{array}$ \\
\hline $\mathrm{CO}_{2}$ & $\begin{array}{c}-71.27 * * \\
(35.81)\end{array}$ & $\begin{array}{l}-67.73^{*} \\
(35.79)\end{array}$ \\
\hline $\mathrm{CO}_{2}$ per GDP & & $\begin{array}{c}-1.884 \\
(4.081)\end{array}$ \\
\hline COASTLINE & $\begin{array}{l}-0.0151 \\
(0.0433)\end{array}$ & $\begin{array}{l}-0.0153 \\
(0.0431)\end{array}$ \\
\hline FREE & $\begin{array}{l}-5.194 \\
(3.515)\end{array}$ & $\begin{array}{l}-5.713 \\
(3.762)\end{array}$ \\
\hline POWERFUL & $\begin{array}{c}-1.498 \\
(3.227)\end{array}$ & $\begin{array}{l}-1.545 \\
(3.210)\end{array}$ \\
\hline Controls & yes & yes \\
\hline Observations & 202 & 202 \\
\hline
\end{tabular}


Table A7: Maximum likelihood estimates in Tobit models (marginal effects of the truncated expected value), country groups: Annex B/non-Annex B

\begin{tabular}{|c|c|c|c|}
\hline \multirow[b]{3}{*}{ VARIABLES } & \multicolumn{3}{|c|}{ Tobit } \\
\hline & (1) & (2) & (3) \\
\hline & $\mathrm{MPR}_{\mathrm{UN}}$ & $\mathrm{MPR}_{\mathrm{UN}}$ & $\mathrm{MPR}_{\mathrm{UN}}$ \\
\hline ANNEX B & $\begin{array}{l}-13.15^{*} \\
(6.966)\end{array}$ & $\begin{array}{l}-13.22^{*} \\
(6.891)\end{array}$ & \\
\hline $\mathrm{CO}_{2}$ & $\begin{array}{l}-34.50 \\
(60.63)\end{array}$ & $\begin{array}{c}-30.41 \\
(64.20)\end{array}$ & $\begin{array}{c}-27.49 \\
(51.70)\end{array}$ \\
\hline $\mathrm{CO}_{2}$ per GDP & & $\begin{array}{c}-1.460 \\
(10.14)\end{array}$ & \\
\hline GDP pc & & & $\begin{array}{l}-0.105 \\
(0.165)\end{array}$ \\
\hline COASTLINE & $\begin{array}{c}-0.0421 \\
(0.103)\end{array}$ & $\begin{array}{r}-0.0425 \\
(0.102)\end{array}$ & $\begin{array}{c}-0.0679 \\
(0.106)\end{array}$ \\
\hline FREE & $\begin{array}{c}3.810 \\
(6.979)\end{array}$ & $\begin{array}{c}3.588 \\
(7.580)\end{array}$ & $\begin{array}{l}-1.369 \\
(7.280)\end{array}$ \\
\hline POWERFUL & $\begin{array}{c}-10.40 * \\
(5.924)\end{array}$ & $\begin{array}{c}-10.46^{*} \\
(5.919)\end{array}$ & $\begin{array}{l}-7.076 \\
(5.773)\end{array}$ \\
\hline Controls & yes & yes & yes \\
\hline Observations & 149 & 149 & 149 \\
\hline
\end{tabular}

Table A8: Maximum likelihood estimates in Tobit models (marginal effects of the truncated expected value), country groups: UNFCCC party groupings

\begin{tabular}{lcc} 
& \multicolumn{2}{c}{ Tobit } \\
\cline { 2 - 3 } VARIABLES & MPR $_{\mathrm{UN}}$ & $\mathrm{MPR}_{\mathrm{UN}}$ \\
\hline AOSIS & 12.93 & 13.44 \\
& $(12.38)$ & $(12.41)$ \\
BASIC & 12.80 & 13.70 \\
& $(13.26)$ & $(13.19)$ \\
EU27 & -6.735 & -6.776 \\
& $(8.745)$ & $(8.754)$ \\
UMBRELLA/EIG & -4.098 & -3.970 \\
& $(9.472)$ & $(9.531)$ \\
$\mathrm{CO}_{2}$ & -68.82 & -58.64 \\
& $(67.58)$ & $(70.93)$ \\
$\mathrm{CO}_{2}$ per GDP & & -4.383 \\
& & $(9.996)$ \\
$\mathrm{COASTLINE}$ & -0.0588 & -0.0604 \\
FREE & $(0.117)$ & $(0.117)$ \\
& -2.711 & -3.640 \\
POWERFUL & $(7.854)$ & $(8.456)$ \\
& $-12.20^{*}$ & $-12.57 *$ \\
Controls & $(6.563)$ & $(6.511)$ \\
\hline \multirow{2}{*}{ Observations } & yes & yes \\
Robust standard errors in parentheses, ${ }^{* * *} \mathrm{p}<0.01,{ }^{* *} \mathrm{p}<0.05,{ }^{*} \mathrm{p}<0.1$
\end{tabular}


Figure A1: Descriptive results on specific minimum participation rules

(i) $\mathrm{MPR}_{\mathrm{UN}}$

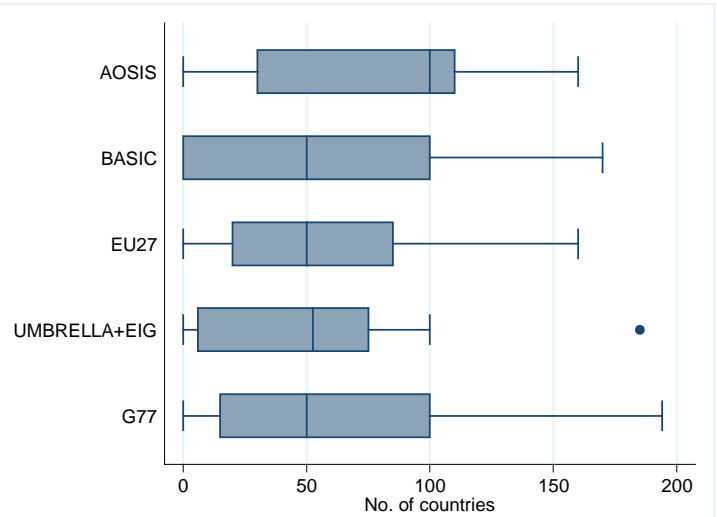

(ii) $M P R_{E M}$

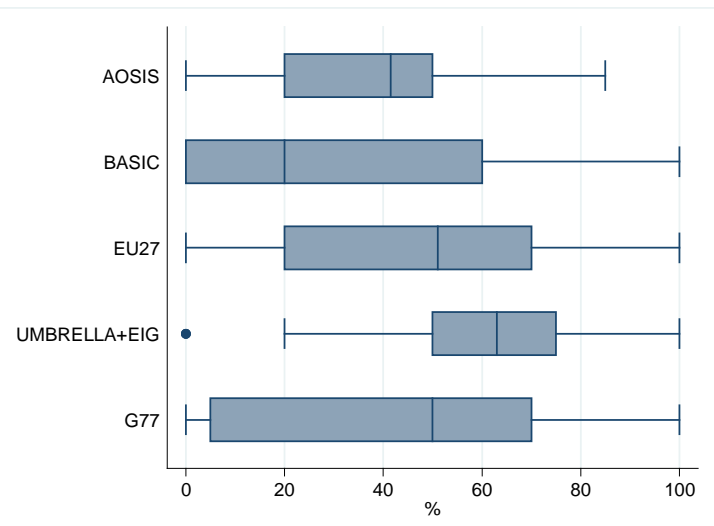

Note: The colored box indicates the lower and upper quartiles of the responses. The subdividing line represents the median. The length of the box represents the interquartile range (IQR). The lines (whiskers) span all data points within 1.5 IQR of the lower or upper quartile and stops at the smallest value (adjacent value). Any further outliers beyond the whiskers are shown individually. See Cox (2009) for more information. 